\title{
REDD+ for the poor or the poor for REDD+? About the limitations of environmental policies in the Amazon and the potential of achieving environmental goals through pro-poor policies
}

\author{
$\underline{\text { Benno Pokorny }}^{1}, \underline{\text { Imme Scholz }}^{2}$ and $\underline{\text { Wil de Jong }}^{3}$
}

\begin{abstract}
Once again, the international community focuses on the preservation of Amazonian forests, in particular through a bundle of initiatives grouped under the term of REDD+. Initially focusing on reducing carbon emissions, the REDD+ process became increasingly linked with developmental goals that represent the primary interest of all Amazon countries. In consequence, REDD+ can be seen as another attempt to achieve the twin goals of environmental protection and rural development, and consequently, relies on the strategies and tools of past efforts. Against this background, we explore past experiences with key strategies for environmental protection and poverty alleviation in the Amazon to critically reflect about the potential of REDD+ to contribute to sustainable local development in the region. The analysis demonstrates that initiatives that pursued environmental goals mostly led to more restrictions and bureaucratic barriers to local forest users, while the prevailing approaches to promote rural dwellers showed ambivalent environmental outcomes. Reasons for these unsatisfactory results include the sectoral alignment of the measures and the poor coordination and lack of coherence with decisive policy areas. Most critically, the environmental and social initiatives themselves rely on the classic development approach widely disregarding smallholders' capacities to contribute to local development. The manifold pilot activities emerging under the new REDD+ framework tend to repeat these shortcomings, thereby further accelerating the replacement of local socio-productive schemes with unsustainable land uses. In view of the growing consensus about the ecological incompatibility, social limitations and economic risks of classic development, an alternative vision of development is needed, which more consciously takes into account the immense social and environmental potential of the region. Considering that REDD+ is still at the start, there might be possibilities to re-adjust the framework and thereby turn it into a real contribution to the sustainable development of rural Amazon.
\end{abstract}

Key Words: Amazon; Development Policies; Forest Management; Poverty Alleviation; REDD+; Rural Development; Sustainability

\section{INTRODUCTION}

Forests have found their way back on the global agenda with the severe consequences of climate change looming. Forest conversion is estimated to contribute $17 \%$ to global $\mathrm{CO}_{2}$ emissions (IPCC 2007), and the world's forests stock store more carbon than is actually contained in the atmosphere (Humphreys 2008). In particular the Amazon region, housing the largest remaining stock of tropical forests and suffering from severe deforestation, is in the focus of the global community because measures to halt the destructive land-use dynamic can significantly reduce future carbon emissions while also protecting biodiversity. Thus, multiple international, national, and local initiatives once again focus on the preservation of Amazonian forests, in particular through a bundle of initiatives grouped under the term REDD+.

This concern about climate change and its consequences is strong, but it competes with the primary interest of the Amazon countries in economic development and the expected positive societal effects. This is particularly true with regards to rural and still forested areas, where poverty is pervasive and living conditions are precarious (UNDP 2010). Exploration of soils, natural resources, minerals, and energy sources located in the
Amazonian region is promoted in the interest of national economic development, in parallel with climate and biodiversity policies. The portfolio of many governments and development banks active in the region reflects this competition: they are engaged in financing both infrastructure and land uses which have severe environmental consequences as well as programs for mitigating climate change and forest protection.

Within this framework of competing agendas, the links between environmental protection and poverty reduction play an important role, mainly for three reasons. First, smallholders in the Amazon region, which we define as comprising indigenous groups, traditional communities, and small-scale settlers, own more than one third of the remaining forests in Latin America (Sunderlin et al. 2008), which makes their resource-use decisions and practices important. Second, social and environmental policies have distributional effects with possibly significant impacts on equity issues and other societal objectives. Finally, the classic view of poverty-induced resource degradation (UN 1987) hints at potentially positive environmental effects of policies targeting the rural poor (Rudel et al. 2005) and is still relevant, despite evidence of

\footnotetext{
${ }^{1}$ University of Freiburg, ${ }^{2}$ Deutsches Institut für Entwicklungspolitik/German Development Institute (DIE), ${ }^{3}$ Centre for Integrated Area Studies of the Kyoto University - CIAS
} 
more complex relationships between poverty and deforestation (Wunder 2001, Angelsen and Kaimowitz 2001, Angelsen and Wunder 2003) and specifically the role of export-oriented large-scale agriculture (Kissinger et al. 2012).

The REDD+ process originated in the climate community and focused on reducing carbon emissions caused by deforestation and degradation. Today, however, REDD+ is increasingly linked to developmental goals. REDD+ initiatives explicitly highlight the benefits to rural forest dwellers, as avoiding deforestation is expected to ensure a supply of daily necessities, the protection of cultural and ethnic habitats, the provision of local environmental services, and, most importantly, the generation of income and employment. Thus, REDD+ can be seen as another attempt to achieve the twin goals of environmental protection and rural development (Kissinger 2011). In the Amazon, however, there are many regulations addressing rural dwellers and their resource-use practices. We explore the effects of past strategies for environmental protection and the support given to poor rural dwellers to identify possible implications and lessons learnt for REDD+ implementation initiatives. This analysis considers two perspectives: the cobenefits for rural dwellers generated by environmental strategies (section 2), and the contribution to forest protection of policies targeting poor rural families (section 3). Finally, in section 4, we discuss the implications of our findings for REDD+ implementation. We conclude that REDD+ projects can be expected to have poor social and environmental outcomes unless they use substantially different approaches, which build on the capabilities of the wide range of local natural resource managers to undertake efficient resource management and conservation in the Amazon.

\section{POVERTY EFFECTS OF STRATEGIES TO ACHIEVE ENVIRONMENTAL GOALS IN FOREST AREAS}

We examine the social relevance of past strategies to protect the Amazon's forests, in particular focusing on regulatory reforms, the introduction of forest concessions, strategic land use planning, forestry projects, and the use of safeguards and environmental standards. For each of these items, we analyzed: (1) the way how these strategies were adapted to generate cobenefits for rural forest dwellers; (2) the success of these adaptations; and (3) the reasons for possible failures.

\section{Introducing and adapting environmental regulations}

Nearly all Amazon governments, supported by international cooperation programs, have adopted environmental regulations that apply to forests and have boosted capacities to enforce them. In general terms they followed a model which is most typically known from the multiple legislative reforms in Bolivia and Brazil (Sabogal et al. 2008a, Carvalheiro et al. 2008, Ibarra et al. 2008, Martinez Montaño 2008, Pokorny in press). By the 1990s, some Amazonian countries had already defined technical norms to promote reduced impact logging.
Simultaneously, governments strengthened related environmental capacities at all levels, from central ministries to municipal authorities, to improve the enforcement of these regulations. Often, this process was accompanied by a transfer of administrative responsibilities to subnational tiers of government.

These reforms did not improve access to forests or to financial benefits for poor forest dwellers (Larson et al. 2006, Pacheco et al. 2012). Therefore, during the 1990s many governments, in accordance with the emerging discourses on sustainable development, self-regulation, and global environmental governance (Arts and Buizer 2009, Arts et al. 2010), started to make their regulatory frameworks more suitable to smallholders who had gained territorial control over large forest lands (Silva et al. 2002). At this time, Ecuador's forestry law, for example, allowed communities to undertake logging using simplified management plans (Planes de Aprovechamiento Forestal Simplificados-PAFSi), and also in Peru, the new forestry legislation foresaw less intensive authorization procedures for indigenous communities (Sabogal et al. 2008a). However, management plans became mandatory for the legal extraction of timber and increasingly also for nontimber forest products. There were some attempts, in particular from Bolivia, Brazil, and Ecuador, to grant communities autonomy to determine their own management schemes. But governments were rarely successful in handing over significant responsibility, control, and resources to smallholder associations (Pacheco et al. 2008). Often, local practices were barred due to legal concerns, different political positions, or administrative incompetence. A drastic example is found in Peru and Bolivia, where the use of chainsaws for preprocessing logs in the forest is strongly restricted, which makes it difficult for smallholders to transport timber from the forest without depending on commercial loggers.

In practice, insufficient administrative and law enforcement capacities of the state, combined with lengthy and extremely bureaucratic processes, strongly limit the possibilities of smallholders to use the regulations to their benefit (Pokorny in press). The vast majority of smallholders have insufficient understanding of regulations or administrative procedures, and hardly any access to external support (e.g., Cano 2012). Even the simplified norms, where they exist, remain highly incompatible with local realities and forest regulations generally suffer from severe inconsistencies with the regulations of other sectors (Pacheco et al. 2008). Most critical is that smallholders do not enjoy indirect conservation benefits, because in many cases the new environmental regulations hardly affect the nonforestry sectors, which continue to cut forests to pursue other land uses.

In this situation, the private sector has started to approach communities to legally access the timber in the forests they now legally own (Lima et al. 2003, Pantoja 2008, Masias 
2011). Logging companies take care of the regulated administrative procedures in exchange for payments of below market value for timber and other goods, for example, the construction of roads and bridges (Benneker 2008, Sabogal et al. 2007). Only companies engaged in FSC certification are sufficiently motivated to comply with legal regulations and maintain good relations with communities, but only a few of them have actually been able to comply with standards for longer periods (FSC-AC 2010).

\section{Forest concessions}

Since the 1990s several Amazonian countries have introduced forest concessions where timber can be exploited in exchange for the payment of royalties. Because of the limited annual growth of commercial timber in tropical forests, usually an area of more than 30,000 hectares is necessary to fully occupy a medium-sized sawmill during a cutting cycle of 20 to $40 \mathrm{yrs}$ (Pokorny and Steinbrenner 2005). Concessions are normally given out in public auctions, and the successful tenderer needs to invest in heavy machinery and equipment, and must comply with strict regulations. In practice, the onerous administrative steps and the significant investment required make it difficult for small and medium-sized logging companies-even with public support (Brazil's National Press 2005)-to successfully participate in such auctions, while smallholders are practically excluded.

Governments have great difficulty with controlling the concession holders that apply predatory harvesting practices, $\log$ more and faster than negotiated, and commonly cut trees outside the authorized area (Gray 2002). During the process of granting concessions, local dwellers' customary and oftentimes even legal land rights are often ignored, so that the concession areas overlap with smallholder lands. Almost always, smallholders living inside or adjacent to forest concessions are seriously constrained in continuing their traditional forest uses (Sabogal et al. 2008a, Carvalheiro et al. 2008, Ibarra et al. 2008, Martínez Montaño 2008). Local employment opportunities are mostly generated in urban areas where the sawmills are located, while in the concession areas the logging companies usually prefer to work with temporary staff from outside the region, even more as the conditions of work are not attractive for most of the locals.

Only in very few cases did smallholder communities obtain concession rights, as for example, in the Ambê initiative in the Tapajós National Park (Brazil) where river communities obtained the right to harvest timber from around 25,000 hectares of public forests (Medina and Pokorny 2008), or in the case of Bolivia where indigenous and multicultural communities have been assured first right to benefit from timber on their extensive communal areas and public forest concessions are allocated to organized urban groups called Agrupaciones Sociales del Lugar (Local Social Groups) (Ruiz 2005). In Brazil, the government established forest settlements
(Projetos de Desenvolvimento Sustentável) where forests are owned and managed collectively. Peru and Bolivia adopted concessions for nontimber forest products, in particular, Brazil nuts (Masias 2011). Also in most indigenous areas and extractive reserve communities receive tenure rights over public forests which include the exclusive rights to commercially use forest products. However, in all these cases the smallholders face insurmountable difficulties to comply with the administrative and technical regulations (Chirif and Garcia Herrero 2007), and the few successful cases strongly rely on massive external support (Medina and Pokorny 2008, 2011, Pacheco et al. 2010).

\section{Strategic land-use planning}

The identification of areas suitable for forest concessions oftentimes coincided with initiatives of strategic land-use planning. Amazonian countries have seen several waves of land-use planning, often associated with extensive natural resource and socio-economic inventories (Pitman et al. 2007). Not unusually, these efforts were motivated, at least in part, by the wish to better control those living in or invading forested regions (Larson and Soto 2008, de Jong and Ruiz 2012). Prominent examples of such initiatives are the National Forest Programs promoted by the World Bank, the Tarapoto Process establishing criteria and indicators for the sustainable management of Amazon forests, and the economic ecological zoning as carried out by Brazil (EFTRN 2004).

The elaboration of plans and supporting studies by different actors at national, subnational, and local levels had important societal effects as they often allowed for an active participation of civil society in public forums and events (see for example the FAO National Forest Program Facility: http://www.nfpfacility.org/en/). These processes generated a platform for exchange between the government, the private sector, science, and civil society, and enhanced the visibility of the environmental sector. However, the multistakeholder dialogue was strongly dominated by environmental NGOs and representatives of the private sector (Pacheco et al. 2008) so that in these dialogues emphasis was consistently given to environmental and economic concerns rather than to social considerations.

While most experiences of forest land-use planning facilitated the timber companies' access to forests traditionally used by local dwellers, it also contributed to the recognition of their customary rights on land and resources through the demarcation of large protected areas. Recent empirical evidence corroborates the protective effect of poor people settling in and around conservation areas, especially when public control could be mobilized (Nelson and Chomitz 2011, Porter-Bolland et al. 2012), but the protected area status had mixed outcomes for their residents (Ehringhaus 2005). Resident families were more effectively protected from outsiders trying to claim land or forests, but also had to observe 
a cumbersome administrative process to commercially use their resources. Traditional land uses could even become legally forbidden, for instance in the case of raising buffalos in the extractive reserve Porto de Moz, in Pará, Brazil.

\section{Forestry development projects}

Sustainable forest management is expected to generate muchneeded income among poor forest dwellers and act as an incentive to reduce deforestation (Homma 2006, Almeida et al. 2006, Hoch et al. 2009). Numerous community forestry projects combined scientific knowledge on forests and professional business models to reorganize the harvest and sale of forest products (Pokorny and Johnson 2008a,b). Mostly, the projects, in search of attractive prices, intended to bypass local intermediaries and fostered local processing of the harvested products for international markets. Most of these projects were internationally funded and implemented by environmental NGOs with well-qualified and motivated staff. The projects were mostly only temporarily financed and invested large human and financial resources in relatively short time periods for a rather limited number of beneficiaries (Pokorny and Johnson 2008b). Most prominent examples of this approach are the ProManejo subprogram of the Pilot Program of the G7 for the Conservation of Brazil's Rainforests (PPG-7) and the project BOLFOR II executed in Bolivia, principally financed by USAID. Similar programs were initiated in the other Amazonian countries (Pokorny and Johnson 2008a).

A different type of program promoted smallholder tree plantations expecting to combine the production of marketable forest products with the restoration of degraded lands. Often these plantation programs provided extensive support only during the establishment phase (Hoch et al. 2009). Also several agroforestry programs were found in the region, however, significantly less frequently and often linked to specialized NGOs (Hoch et al. 2009, Almeida et al. 2006, Chapin 2004, Simmons et al. 2002, UNDP 1997). These programs promoted the simultaneous production of agricultural crops and trees to effectively use the long-term ecological potential of the land (Milz 1997).

In general, smallholders were able to comply with these new externally defined modes of operation, but only with significant external support for equipment, machines, material, training, remuneration and technical advice, and commercialization (Medina and Pokorny 2011, Pokorny et al. 2012). Participating smallholders were often able to strengthen their formal organization and to gain managerial capacities, in particular with regard to finances and information (Donovan et al. 2008). Many smallholders started to interact more intensively with nonlocal actors and the public administration (Humphries and Kainer 2006, Ros-Tonen et al. 2008), and were able to establish beneficial new partnerships with supporting organizations (Medina et al. 2009a). The projects stimulated social organization and local capacities to more adequately respond to external opportunities and threats, and to break from the subjugated relationships still common in the region (Sabogal et al. 2008b).

But smallholders suffered from severe competitive disadvantages in comparison to professional private companies, when trying to master the required administrative and organizational skills, and assure the increased resource inputs (Pokorny et al. 2012). The costs of implementing the new technologies and organization normally exceeded local capacities and resources. Often the promoted land uses suggested because of their positive environmental outcomes, were economically less attractive than anticipated (Hoch et al. 2009, 2012, Medina and Pokorny 2011), and smallholders' benefits remained marginal compared to alternative options. Even in successful community forestry projects, for example, profits rarely exceeded $5 \mathrm{USD} / \mathrm{ha} / \mathrm{yr}$ (Pokorny in press). Even when profits were generated, smallholders were rarely able to accumulate sufficient capital to secure operations in subsequent years (Medina and Pokorny 2011), and sales in national and international markets remained difficult making them dependent on the continued mediation by NGOs (Scherr et al. 2001, Hoch et al. 2012, Pokorny et al. 2012).

The great majority of Amazonian forestry development projects, therefore, had surprisingly few lasting positive effects on the local situation (Hoch et al. 2009, Gasche 2004). Many families decided to resume their traditional management schemes upon conclusion of such projects. A spontaneous replication of the technological-organizational packages promoted by these projects hardly ever took place (Pokorny and Johnson 2008a) so that success stories remain isolated examples (Pokorny and Johnson 2008b).

\section{Safeguards and standards}

By the 1990s, international financial institutions such as the World Bank recognized the need to mitigate environmental and social side effects of their investments, so they began to develop safeguards to avoid unintended harm to local people and ecosystems (Dani et al. 2011). More recently, the UNFCCC further expanded this 'do no harm' policy to more substantive and procedural goals valid across all types of investments independent from the source of finance (Kanowski et al. 2011). The Cancun Agreement (UNFCCC 2011) called for "respect for the knowledge and rights of indigenous peoples and members of local communities ... [as well as] ... the full and effective participation of relevant stakeholders, in particular indigenous peoples and local communities".

McDermott et al. (2012) attested that social safeguards within forest carbon schemes "have pioneered the concept of 'additionality' of social benefits". Considering the disparate actors, interests and ideas involved, however, they remain skeptical if and in how far these safeguards will be able to 
influence the way these schemes will be implemented on the ground. One of the few studies on the adoption of REDD+ safeguards (Steni et al. 2012) observes that diplomacy in governmental negotiations and the tools available to official development cooperation limit the scope of conditionality and accountability that donors may expect. The monitoring of agreed upon targets takes place at a highly aggregated level, and compliance can be assessed only after funding has been committed. The study thus concludes that current bilateral donor policies can hardly guarantee compliance with safeguard standards. The COP17 in Durban 2011 explicitly called for providing finance for result-based REDD+ action only in the context of robust, participatory, and transparent national systems in order to demonstrate that safeguards are addressed and respected throughout all phases of the action (UNFCCC 2012). But compliance with this call will continue to depend on the explicit commitment to these safeguards of all actors involved (donors, financial institutions, implementing agencies, and governments) (Bursche 2012). The magnitude of the challenge becomes visible by the fact that only Brazil and (soon) Mexico have managed to develop national safeguards, while Indonesia, the second largest receiver of REDD+ funding after Brazil has not achieved this yet (Steni et al. 2012).

The categorical requirement to comply with social safeguards might negatively affect the possibility of smallholders to become implementers of environmental investments themselves. In fact, the generation of norm cascades (Finnemore and Sikkink 1998) systematically favors financially better endowed actor groups because of their specialized business model and their greater capacity to fulfill technical and bureaucratic requirements (Pokorny et al. 2012). This is particularly visible in the experiences with the EU FLEGT Action Plan to exclude illegal timber from European markets (Brown et al. 2009) and may even worsen with the EU timber regulation that will come into force in 2013. Also the instruments for organic, social, and environmental certification tend to marginalize small producers due to their limited administrative and financial capacities (Phillip and Pokorny 2008). In the case of FSC certification of community forestry, for example, the compliance costs normally exceed market premiums of certified timber (Medina and Pokorny 2008). Some norms might also be in conflict with local practices such as the prohibition or strong restriction of hunting or the expansion of agricultural fields in designated forest management areas (Benneker 2008) or of engaging the entire family, possibly including underage children, in the working process (Homma 2006).

\section{ENVIRONMENTAL EFFECTS OF PRO-POOR POLICIES IN FOREST AREAS}

Here we explore the environmental outcomes of poverty alleviation measures targeted towards poor rural families by examining three key strategies pursued by Amazonian countries: the formal recognition of traditional rights on land and resources, credit programs for small-scale farmers, and transfer payments to poor rural dwellers. For each strategy, we sketch its rational, describe the modes of operation and then outline the specific environmental outcomes.

\section{Recognition of local rights}

There is wide consensus that secure rights over customary owned land and resources is a prerequisite for smallholders' effective use of forests and sustainable development (Larson et al. 2010, Sikor and Stahl 2011). Individual or collective ownership is expected to stimulate long-term investments and restrain owners from inappropriate land uses, including the predatory harvest of forest products, and to constrain largescale conversion of forest land to commercial uses (Agrawal 2007, Cano 2012). Legal land ownership might also restrain dam and mining projects because the landowners are entitled to resettlement support and compensation payments.

Since the $19^{\text {th }}$ century, when legal private landownership was first introduced in the Amazon, a huge proportion of land has been transferred to local elites (Wienold 2006, Keen and Haynes 2009). In the second half of the last century, agrarian reforms systematically further encouraged the privatization of land (Bunker 1985, Keen and Haynes 2009) along newly constructed roads. Amazonian residents were massively threatened by the often-violent newcomers. Only recently have some countries started to formally recognize the territories of indigenous groups and other long-term residents. But progress of the ambitious programs to issue land titles to smallholders has been slow partially because of frequently overlapping ownership claims (Wagner 2008). The bureaucratic processes for demarcation and clarification may easily take more than 10 years (Pacheco et al. 2012). In consequence, many smallholders still face issues with unresolved land titles (Chirif and Garcia Hierro 2007).

The experiences with individual land titling show that the specific environmental outcomes depend on the actor type, the features of the properties, and the wider socio-economic and political environment. Indigenous groups, for example, tend to continue with their more extensive customary land uses after receiving collective land titles over large areas of forestlands (Schmink and Wood 1992, Chirif and Garcia Hierro 2007). This reinforces the argument that indigenous territories are a safety belt against the expansion of estate agriculture. However, some indigenous territories have been heavily threatened by logging companies which often negotiate with local leaders interested in individual benefits (Medina et al. 2009b, Cano 2012) and by illegal invasions of gold seekers and settlers (Tacconi 2007). Indigenous reserves also frequently suffer from expropriations for mining or the construction of dams and other infrastructure projects (BID 2006). Nonindigenous long-term forest dwellers that received collective property rights had similar experiences with 
external pressures. However, they showed a higher disposition to abandon their land and to migrate to urban centers (Padoch et al. 2008, Cano 2012).

In contrast, small-scale farmers, if settled on poor soils and far from urban areas and markets, tend to abandon their land in search for a better living after having gradually transformed their forests with nonsustainable land-uses. Individual land titles facilitate this dynamic, although land is also sold without them. For many smallholders, settling at an agricultural frontier and selling land after a while has become part of their livelihood strategy (Hecht 2011). But also settlers with holdings on fertile soils and better market access transform their forests into other land uses economically more attractive to them, and this is independent from the specific legal land status (Pokorny in press). However, under such favorable conditions, settlers may also continue to reside on their legally recognized properties and create environmentally stable cultivated landscapes (Godar et al. 2012, Pokorny et al. 2012).

\section{Credit programs}

As smallholders generally suffer from a lack of capital, the provision of credit is a quite popular policy to address local people (Pokorny and Johnson 2008b). Credit can be used for investments in improved land use, processing, and commercialization. In addition to acquiring agricultural inputs, smallholders also use credit for housing and the purchase of electric appliances such as refrigerators, televisions, and cell phones, or to pay for the education of their children. The outreach of credit programs is wide as the banking system is already established in most of the rural towns throughout the Amazon. Credit can generate positive environmental outcomes if invested in a more effective use of natural resources thereby guarantees well-being and stability in the long run.

Public credit programs in the Amazon mostly target actors who are better off and are often already engaged with commodity markets (Pokorny et al. in press). Although the programs have become more flexible, poor families, in particular those belonging to indigenous groups and other long-time resident groups, still have little chance to overcome the bureaucracy and to fulfill the formal requirements to obtain a credit (Zeller and Meyer 2002). In many cases, the banks do not accept small rural properties as collateral for loans, either because land tenure is not formalized, the value of the land is too low, or because the families live on common or publicly owned land in which the individual smallholding cannot be impounded. The few programs of governments, banks, and NGOs explicitly designed for poor rural dwellers normally require membership in a formal organization. This has resulted in the emergence of a huge number of associations, most of them, however, very weak and often disbanded after receiving the targeted support.
Generally, public credit programs for smallholders are linked to the transfer of technology packages by rural extension services (Pokorny and Johnson 2008b). The vast majority of existing credit programs pursues agricultural modernization: they focus on the production of specific crops for regional and export markets and are geared to regions with longer agricultural tradition, stronger infrastructure, and higher degrees of market integration. In consequence, they are often poorly adapted to the realities and demands of Amazonian smallholders, who in general have a lower level of mechanization and typically produce both for markets and their own consumption.

Historically, public credits and incentives have played a critical role in the expansion of unsustainable land uses in the Amazon, most prominently cattle ranching in Brazil (Mahar 1988, Arima et al. 2002, Pacheco 2009). Only in recent years has cattle ranching become a profitable private operation (Margulis 2004). In many cases the large-scale transformation of forests for capital-intensive mono-crop agriculture and pastures has been only possible with credits and other subsidies. This has often been to the detriment of forests, and more traditional and rather diversified small-scale production systems which are more compatible with the specific environmental conditions in the region (Pokorny et al. in press) and disappear together with the forests (Fearnside 2005, de Schutter 2011). Poorer smallholders who managed to obtain credit tended to ignore the rigid rules and instead used funding for their most urgent needs or personal preferences. This frequently included the purchase of cattle or new land for cattle ranching (Herrera 2011). Rarely, did investments in agricultural intensification diminish the pressure on remaining forests (Angelsen and Kaimowitz 2001).

\section{Transfer payments}

Revenues generated outside the smallholders' own property are increasingly gaining importance for the livelihoods of rural families (Pokorny in press). This includes public cash transfer programs and other sources of financial transfers. For example, the Bolsa Família program established by the Brazilian government finances scholarships for children from about 12 million poor families who, in exchange, have to guarantee that their children attend school and are vaccinated (see http://www.mds.gov.br/bolsafamilia). Also in Peru, where about half of the population lives below the poverty line, there are several programs to assist the poorest families, for example through funds such as the FONCODES (Fondo de Cooperación para el Desarrollo Social) that invest in facilities and infrastructure to support micro- and small enterprises. In Bolivia, the government, since its widereaching political reforms, has started distributing a major part of its national budget to local governments which are tasked with addressing pressing issues at the local level. An important 
share of rural cash income which is channeled through these programs originated from the National Emergency Employment Plan (Fuentes et al. 2005) that is funded through revenues earned with taxes on hydrocarbon exploitation and from funds that were established to offset debts with international lenders. In many countries, the payment of oldage pensions has become an even more important source of poor families' cash income (Schwarzer and Querino 2002, Dethier et al. 2010). Although public pension schemes generally suffer from significant administrative deficits and high fiscal costs, in many countries an increasing proportion of older people benefit from such schemes. Families also increasingly depend on financial transfers from relatives working in the rapidly emerging urban centers, in large national metropolitan areas, or even abroad. Finally, humanitarian organizations including the churches, private foundations, and NGOs occasionally distribute aid in form of financial support, but more often as food or other materials.

Compared to credit programs, these transfer payments are generally smaller, but more regular, and less subject to conditions and bureaucracy. Therefore many poorer families have a chance to benefit. Many of these payments are similar to a basic income guarantee as described by Gorz (1984), and thus might create space for local innovations and adaptations towards a more effective use of environmental resources. Most of the poor families tend to use these payments for needs such as food, education, and housing rather than for production purposes. But these transfers might allow for some capital accumulation over time, in particular if supported by the often significant remittances from family members working elsewhere, and this may also lead to larger productive investment. The degree to which transfer payments might encourage smallholders to expand unsustainable land uses with their negative environmental effects depends on the specific situation of the household and the level of capital accumulation.

\section{DISCUSSION}

The above findings demonstrate a rather limited success of the major strategies to fight environmental destruction and poverty in achieving the twin goals of environmental protection and local development. Initiatives that pursued environmental goals often led to more restrictions and bureaucratic barriers to maintain or improve forest incomes of smallholders. The transaction costs related to addressing the requirements of legal forest use, too often outweighed incomes that could be obtained in return (Pokorny et al. 2012). Without massive external support, especially poor smallholders were not able to compete with more qualified and better endowed actors in their attempt to access eventual benefits from environmental policies (Medina and Pokorny 2008). As deforestation continues, environmental policies also failed to conserve the basis for the livelihoods of many, especially poor, families in the region.
Also, the prevailing policy approaches to improve living conditions of rural dwellers showed variable environmental outcomes. Securing local land tenure might have positive environmental outcomes, but this largely depends on whether economic framework conditions are favorable to the livelihoods of smallholders. Under unfavorable conditionspredominate in vast parts of the region-the granting of individual property rights might even accelerate the transformation of forests into other land uses because titled land is easier to sell. Credit programs generally enhanced the probability of deforestation because it was considered from an economic point of view as an investment in future land use (Wunder 2001). The negative environmental consequences of agricultural credit programs are aggravated by the fact that they mostly promote input-intensive production rather than agroecologically efficient agricultural systems for small farmers (de Schutter 2011, Altieri et al. 2012). In this sense, the findings confirm that without explicit public policies aiming at securing the social and environmental sustainability of agricultural change, higher levels of economic well-being generally go along with high environmental costs (ERD 2012).

\section{Reasons for failure}

These unsatisfactory results partly stem from the marginality of the sectoral measures and the poor coordination and lack of coherence with other more relevant policy areas. Environmental or social measures alone are not able to significantly affect a policy framework that aims at promoting development mainly through economic growth. Such approaches lead to critical processes such as (i) the expansion of the agricultural frontier driven by large-scale investors that aim at producing cash crops and cattle for domestic or foreign markets, (ii) the construction of roads and ports for the connection to international markets, (iii) large investments in hydropower plants as a relevant source of renewable energy in order to implement national low-carbon development strategies, and (iv) the exploitation of oil, gas and minerals (de Jong et al. 2010, Scholz 2005). These processes have detrimental effects on local rural incomes and forest stocks.

Most critical, a major share of the environmental and developmental projects themselves follows market-oriented approaches that widely ignore local management practices, local ways of organizing work, and other local capacities and limitations. They also require different knowledge and organizational skills, and the use of new technologies and increased resource inputs (Porro et al. 2008, Pokorny and Johnson 2008b, Pokorny et al. 2012). Even many development organizations that aim at improving smallholders' livelihoods implicitly question whether local socio-productive systems can effectively contribute to a sound rural development. In addition, these organizations uncritically assume that their cultural logic of sustainable development also applies to the smallholders. The majority of sustainable forestry development projects, for instance, demand that Amazonian 
rural dwellers adopt working routines and commitments which require attitudes that are essentially alien to their culture (Gasche 2010, Gasche and Vela 2012). As a consequence, many projects concentrate on adapting local families to externally defined models for development and conservation and their impacts vanish once the external support comes to an end (Pokorny in press).

\section{Can REDD+ change the picture?}

Considering the scope of the manifold REDD+ initiatives launched so far, it is questionable if and in how far REDD+ will be able to avoid the observed shortcomings. Thus far, the numerous readiness activities primarily invest in generating institutional capacity to implement REDD+ action, in particular for administration of funding, strategic planning and carbon monitoring (Cerbu et al. 2010, Kissinger et al. 2012). Generally, these efforts mimic older efforts for the operationalization of the sustainable forest management approach occurring in the follow up of the Rio summit in 1992. As REDD+ most probably will be implemented at national scale and must comply with internationally determined mitigation obligations, these efforts run the risk of reinforcing classic centralized administration rather than fostering innovative local governance schemes. This is particularly the case regarding the enforcement of environmental regulations and the demarcation and administration of parks and other conservation areas. At the local level, there is evidence that REDD+ initiatives in practice do not differ too much from past efforts to halt deforestation (Angelsen et al. 2012). The vast majority of demonstration activities already work with socalled Integrated Conservation and Development Projects that mostly invest in enabling local resource users to follow the technical and legal standards for sustainable resource management developed by nonlocal experts, often, but not always, accompanied by rather moderate direct payments to the resource users. In practice, these pilot initiatives also struggle with issues like rights to land, forest, or carbon (Karsenty et al. in press), that have inhibited progress in local development for decades. Thus, although considering a broader array of practices such as for example climate-smart agriculture (FAO, 2010), no structural impulses are to be expected.

Also Payments for Environmental Services (PES), originally being the most significant innovation brought in from the REDD+ debate, in practice will have little chance to significantly change the picture. In fact, only $23 \%$ of REDD+ readiness plans foresee such payments (Kissinger et al. 2012). Experiences from pilot initiatives already indicate that due to immense transaction costs at organizational but also local level, effective payments to the individual families will remain marginal (Viana 2010, Sato 2011). For accessing scarce available carbon funding, projects have to guarantee additional emission reductions. This requirement can hardly be fulfilled by settlers as they tend to gradually transform the forests within their properties over time, with or without payment. Thus, the condition of additionality would have to be changed in order to adapt REDD+ funding to the fact that a huge proportion of tropical forests is locally owned (Sunderlin et al. 2008) and that opportunity costs of poor rural dwellers are typically low (Börner and Wunder 2008). Also the bureaucratic requirements related to baseline studies, monitoring, negotiations, and contracts, strongly limit accessibility of payments (Engel et al. 2008). In addition, institutional preparations for REDD+ have resulted in complex political processes at the national level for which a positive outcome is not yet ensured (Erler et al. 2011, Angelsen et al. 2012). The availability of funding for PES schemes is a more and more open question, in particular considering that the relative importance of deforestation for mitigating climate change is drastically decreasing with growing economies in the developing world and associated increases in the use of fossil energy sources (le Quéré et al. 2009, van der Werf et al. 2009).

\section{CONCLUSIONS}

Our analysis has shown that current approaches to achieving environmental and social goals in the Amazon are not effective given their insufficient or negative impacts on local development. This conclusion is reinforced by the growing consensus about the ecological incompatibility, social limitations, and economic risks of the conventional approach to prosperity (Jackson 2009, Randers 2012). In contrast, local development policies in the Amazon region should be grounded in a holistic development concept, which is more compatible with the conditions, resources, and capacities actually existing in the Amazon. There is evidence that the richness of local production models and cultures might be more appropriate for guiding such a concept than modernization strategies based on a stylized interpretation of the very specific experiences of industrialized countries. Already since the 1980s, anthropologists commented on indigenous forest management and forest restoration among indigenous groups (e.g., Posey et al. 1983). Similar practices have been reported for nonethnic rural residents of the Amazon, the caboclos of Brazil, ribereños of Peru and similar groups in other countries (Parker 1985, Posey and Balee 1987, Padoch and de Jong 1987). These cases include multiple examples of market-oriented natural forest management, agroforestry production, and tree plantations scattered throughout the Amazon basin (Padoch et al.1985, Brondizio et al. 2002, Hoch et al. 2009).

Exploring smallholders' potential for local development To strengthen local cultures and practices instead of searching for their replacement might generate prosperity while avoiding the further propagation of unsustainable land uses. At a more general level, it is relevant to explore the conditions needed for effectively stimulating and supporting these local potentials. These include sufficient and secure resources, 
access to attractive market schemes, effective collaboration between social and commercial networks, adequate and reliable public support, an adequate regulatory framework, and effective law enforcement including the protection of rural dwellers against the interests of more powerful actors (Zenteno 2012, Pokorny in press).

This, however, is far away from the conditions found in the region, which are still characterized by historically unfair power structures, and where changes in land use respond to powerful global processes instead of local needs and priorities. In fact, public and private investment in infrastructure for local economic and social development has traditionally been very low in the Amazon, and the unfulfilled needs in this regard are immense. It is therefore fundamental that the responsibility of promoting productive potentials in the region and supporting local social systems is taken up by the responsible ministries and departments instead of shifting this task into the field of environmental policies. If environmental, economic, and social public policies are conceived as a complementary package, based on local needs, and are carefully coordinated, the chances of achieving the twin objectives of poverty alleviation and forest conservation are more real. Nevertheless, the chances for such drastic changes in public policies are low.

\section{REDD+, however, is a chance}

The analysis presented so far clearly indicates that if governments want to achieve lasting results with REDD+ programs, they have to drastically change their public policies for the Amazon. But the REDD+ readiness programs indicate the risk of repeating the errors of past external policy interventions. In addition, the indecision about scope and scheme of the funding makes it highly uncertain that Amazonian countries will adopt the policies proposed by the REDD+ model to achieve their ambitious mitigation goal by reducing $60 \%$ of their emissions from deforestation and other land-uses (den Elzen et al. 2012). Even if they did, our analysis suggests that such policies would primarily benefit marketintegrated economic actors with secure land titles not smallholders. In fact, potential carbon projects already have attracted entrepreneurs who seek profit by luring local communities into signing carbon deals with false and detrimental promises (e.g., Wiesse 2012). The REDD+ funds that will probably continue to rely on donors will be primarily used for second best policy approaches, e.g., strengthening institutions and technologies necessary for monitoring and law enforcement, and promoting productivity increases in smallholder agriculture (Angelsen et al. 2012). More and more proponents of financial environmental incentives do recognize that it is the wealthier segments of society that are better able to obtain legal authorizations, subsidies and premiums (Hall 2008, Engel et al. 2008).

Nevertheless, the debates around REDD+ have made important contributions to raising awareness about the linkages and trade-offs between social and environmental issues, as is visible in the debate on social safeguards. At the same time, the dynamic in post-frontier areas characterized by the abandonment of agricultural lands and the emergence of locally embedded urban-rural networks, as well as the still existing environmental and cultural capital of the region in combination with the increasing interest of society in alternative models for sustainable development entail enormous opportunities. Considering that REDD+ is still in the early stages, there might be possibilities to re-adjust the framework and thereby turn it into a real contribution to the sustainable development of the rural Amazon.

Responses to this article can be read online at: http://www.ecologyandsociety.org/issues/responses. $\mathrm{php} / 5458$

\section{Acknowledgments:}

Several activities leading to this paper were supported by the European Community's projects: Forest management by small farmers in the Amazon - An opportunity to enhance forest ecosystem stability and rural livelihood (Acronym ForLive, INCO no. PL 510903) and Governança de Recursos Naturais por Pequenos Produtores Rurais da Amazônia (Acronym GOL, EuropeAid no. 128-046/L/ACT/BR, DCI-

NSAPVD/2010/208-221), as well as the Japan Society for the Promotion of Science (JSPS) Grant-in-aid for Scientific Research: Transnational Natural Resource Governance in Borderlands, and by the JSPS funded Global Centres of Excellence (COE) Program: Towards Sustainable Humanosphere in Asia and Africa. We are grateful to the editors of the special feature for inviting us as well as the anonymous reviewers for their excellent observations.

\section{LITERATURE CITED}

Agrawal, A. 2007. Forests, governance, and sustainability: common property theory and its contributions. International Journal of the Commons 1(1):111-136.

Almeida, E., C. Sabogal, and S. Brienza. 2006. Recuperação de áreas alteradas na Amazônia Brasileira: experiências locais, lições aprendidas e implicações para políticas públicas. CIFOR, Bogor, Indonesia.

Altieri, M., F. Funes-Monzote, and P. Petersen. 2012. Agroecologically efficient agricultural systems for smallholder farmers: contributions to food sovereignty. Agronomy for Sustainable Development 32(1): 1-13. http://dx.doi. org/10.1007/s13593-011-0065-6

Angelsen, A., and D. Kaimowitz, editors. 2001. Agricultural Technologies and Tropical Deforestation. CABI Publishing, 
Wallingford, Oxon, UK. http://dx.doi.org/10.1079/9780851$\underline{994512.0000}$

Angelsen, A. and S. Wunder. 2003. Exploring the Forest Poverty Link: Key Concepts, Issues and Research Implications. Occasional Paper 40. CIFOR, Bogor, Indonesia.

Angelsen, A., M. Brockhaus, W. D. Sunderlin, and L. V. Verchot, editors 2012. Analysing REDD+: Challenges and Choices. CIFOR, Bogor, Indonesia.

Arima, E., R. R. Schneider, A. Veríssimo, C. Souza, and P. Barreto. 2002. Sustainable Amazon: Limitations and Opportunities for Rural Development. World Bank Technical Papers 515. World Bank, Washington D. C., USA.

Arts, B. and M. Buizer. 2009. Forests, discourses, institutions. A discursive-institutional analysis of global forest governance. Forest Policy and Economics 11:340-347. http:// dx.doi.org/10.1016/j.forpol.2008.10.004

Arts, B., M. Appelstrand, R. Eba'a Atyi, T. Enters, I. Hamakers, D. Kleinschmit, H. Pülzl, K. Visseren-McGinley, and Y. Yasmi. 2010. Discourses, Actors and Instruments in International Forest Governance. Embracing Complexity Meeting the Challenges of International Forest Governance. IUFRO World Series 28:57-73. [online] URL: http://www. iufro.iurg/science/gfep/forest-regime-panel/report/

Benneker, C. 2008. Dealing with the State, the Market and NGOs: The Impact of Institutions on the Constitution and Performance of Community Forest Enterprises (CFE) in the Lowlands of Bolivia. PhD thesis. University of Wageningen, Wageningen, The Netherlands.

Banco Interamericano de Desarrollo (BID). 2006. Construyendo un nuevo continente. Un enfoque regional para fortalecer la infraestructura sudamericana. BID, Washington D. C, USA.

Börner J., and S. Wunder. 2008. Paying for avoided deforestation in the Brazilian Amazon: from cost assessment to scheme design. International Forestry Review 10 (3):496-511. http://dx.doi.org/10.1505/ifor.10.3.496

Brazil's National Press. 2005. Lei $n^{\circ} 11$. 284/06. Diário Oficial da União. (O livro branco da grilagem de terras no Brasil). INCRA, Brasília, Brazil.

Brondizio, E. S., C. A. M. Safar, and A. D. Siqueira. 2002. The urban market of açaí fruit (Euterpe oleracea Mart. ) and rural land use change: ethnographic insights into the role of price and land tenure constraining agricultural choices in the Amazon estuary. Urban Ecosystems 6:67-97. http://dx.doi. org/10.1023/A:1025966613562

Brown, D., K. Schreckenberg, N. Bird, P. Cerutti, F. Del Gatto, C. Diaw, T. Fomete, C. Luttrell, G. Navarro, R. Oberndorf,
H. Thiel, and A. Wells. 2009. Legal timber verification and governance in the forest sector. ODI, London, GB.

Bunker, S. 1985. Underdeveloping the Amazon: Extraction, Unequal Exchange, and the Failure of the Modern State. University of Illinois Press, Champaign, IL, USA.

Bursche, A. 2012. The Implementation of REDD+ Safeguards in Bilateral German Development Cooperation. An Application of Street-level Bureaucracy. MSc. thesis. University Freiburg, Freiburg, Germany.

Cano, W. 2012. Formal Institutions, Local Arrangements and Conflicts in the Northern Bolivian Communities after Forest Governance Reforms. Phd thesis. Scientific Series 15. Utrecht University, Utrecht, The Netherlands.

Carvalheiro, K., C. Sabogal, and P. Amaral. 2008. Análise da legislação para o manejo florestal por produtores de pequeña escala na Amazônia brasileira. CIFOR, Belém, Brazil.

Cerbu, G. A., B. M. Swallow, and D. Y. Thompson. 2010. Locating REDD: a global survey and analysis of REDD readiness and demonstration activities. Environmental Science and Policy 14(2):12. http://dx.doi.org/10.1016/j. envsci.2010.09.007

Chapin, M. 2004. A challenge to conservationists. World Watch Magazine, 11 December 2004. UNO/BOL/723/DCP.

Chirif, A. and P. García Hierro. 2007. Marcando territorio: progresos y limitaciones de la titulación de territorios indígenas en la Amazonía. International Working Group for Indigenous Affairs, Copenhagen, Denmark.

Dani, A., A. Freeman, and V. Thomas. 2011. Evaluative Directions for the World Bank Group's Safeguards and Sustainability Policies. Evaluation Brief 15. World Bank, Washington D. C., USA.

De Jong, W., J. Börner, P. Pacheco, B. Pokorny, C. Sabogal, C. Benneker, W. Cano, C. Cornejo, K. Evans, S. Ruiz, and M. Zenteno. 2010. Amazon forests at the crossroads: pressures, responses, and challenges. Pages 283-298 in R. Alfaro, M. Kanninen, M. Lobovikov, G. Mery, B. Swallow, and J. Varjo, editors. Future of Forests - Responding to Global Changes. IUFRO, Vienna, Austria.

De Jong, W., and S. Ruiz. 2012. Strangers among trees: Territorialisation and forest policies in the northern Bolivian Amazon. Forest Policy and Economics 16:65-70. http://dx. doi.org/10.1016/j.forpol.2011.02.004

Den Elzen, M., M. Roelfsema, A. Hof, H. Böttcher, and G. Grassi. 2012. Analysing the Emission Gap Between Pledged Emission Reductions under the Cancún Agreements and the $2{ }^{\circ} \mathrm{C}$ Climate Target. PBL Netherlands Environmental Assessment Agency, The Hague/Bilthoven, The Netherlands. 
De Schutter, O. 2011. How not to think of land-grabbing. Three critiques of large-scale investments in farmland. Peasant Studies Journal 38(2):249-279. http://dx.doi. org $/ 10.1080 / 03066150.2011 .559008$

Dethier, J. J., P. Pestieau, and R. Ali. 2010. Universal Minimum Old Age Pensions. Impact on Poverty and Fiscal Cost in Latin American Countries. Policy Research Working Paper 5292. World Bank, Washington D. C., USA.

Donovan, J., D. Stoian, and N. Poole. 2008. A global review of rural community enterprises. Rural Enterprise Development Collection 2. CATIE, Turialba, Costa Rica.

European Tropical Forest Research Network (EFTRN). 2004. National forest programmes. EFTRN News 41-42.

Ehringhaus, C. 2005. Post-victory Dilemmas: Land Use, Development Policies, and Social Movement in Amazonian Extractive Reserves. $\mathrm{PhD}$ thesis. Yale University School of Forestry and Environmental Studies, New Haven, CT, USA.

Engel, S., S. Pagiola, and S. Wunder. 2008. Designing payments for environmental services in theory and practice: an overview of the issues. Ecological Economics 65 (4):663-674. http://dx.doi.org/10.1016/j.ecolecon.2008.03.011

European Development Report (ERD). 2012. Confronting Scarcity: Managing Water, Energy and Land for Inclusive and Sustainable Growth. ODI, London, GB.

Erler, D., S. Frank, J. Hein, H. Hotz, A. Santacruz Melgarejo, and F. Zelli. 2011. Inclusión social en el proceso REDD en el Perú: una perspectiva de gobernanza en múltiples niveles. DIE/BMU/GIZ, Lima, Peru. [online] URL: http://www. diegdi. de

Food and Agricultural Organization of the United Nations (FAO). 2010. Climate-smart agriculture. Policies, practices and financing for food security, adaptation and mitigation. Background paper for the Hague Conference on Agriculture, Food Security and Climate Change, held 31 October to 5 November 2010. FAO, Rome, Italy.

Finnemore, M., and K. Sikkink. 1998. International norm dynamics and political change. International Organization 52 (44):887-917. http://dx.doi.org/10.1162/002081898550789

Fearnside, P. M. 2005. Deforestation in Brazilian Amazonia: history, rates, and consequences. Conservation Biology 19 (3):680-688. http://dx.doi.org/10.1111/j.1523-1739.2005.00697. $\underline{\mathrm{x}}$

Forest Stewardship Council - Asociación Civil (FSC-AC). 2010. Global FSC certificates, types and distribution. FSC, Bonn, Germany.

Fuentes, D., R. Haches, R. Maldonado, M. Albornoz, P. Cronkleton, W. de Jong, and M. Becker. 2005. Pobreza, descentralización y bosque en la Amazonia Boliviana. CIFOR, Bogor, Indonesia.

Gasche, J., editor. 2004. Crítica de proyectos y proyectos críticos de desarrollo: una reflexión latinoamericana con énfasis en la Amazonia. IAP, Iquitos, Peru.

Gasche, J. 2010. La ignorancia reina, la estupidez domina y la conchudez aprovecha. Engorde neo-liberal y dieta bosquesina. Revista Espaço Pedagógico 17(2):279-305.

Gasche, J., and M. N. Vela. 2012. Sociedad bosquesina Vol. 1. Ensayo de antropología rural amazónica, acompañado de una crítica y propuesta alternativa de proyectos de desarrollo. IAP, Iquitos, Peru.

Godar, J., J. Tizado, and B. Pokorny. 2012. Who is responsible for deforestation in the Amazon? A spatially explicit analysis along the Transamazon Highway in Brazil. Forest, Ecology and Management 267:58-73. http://dx.doi.org/10.1016/j. foreco.2011.11.046

Gorz, A. 1984. Wege ins Paradies. Rotbuch Verlag, Berlin, Germany.

Gray, J. 2002. Forest Concession Policies and Revenue Systems - Country Experience and Policy Changes for Sustainable Tropical Forestry. World Bank Technical Paper 522. World Bank, Washington D. C., USA.

Hall, A. 2008. Better RED than dead: paying the people for environmental services in Amazonia. Biological Sciences 363 (1498):1925-1932. http://dx.doi.org/10.1098/rstb.2007.0034

Hecht, S. 2011. The Scramble for the Amazon and the "Lost Paradise" of Euclides da Cunha. University of Chicago Press, Chicago, IL, USA. http://dx.doi.org/10.7208/chicago/97802$\underline{26322834.001 .0001}$

Herrera, J. A. 2011. Desenvolvimento capitalista e realidade da produção agropecuária familiar na Amazônia Paraense. $\mathrm{PhD}$ thesis. UNICAMP, Campinas, Brazil.

Hoch, L., B. Pokorny, and W. de Jong. 2009. How successful is tree growing for smallholders in the Amazon? International Forestry Review 11(3):299-310. http://dx.doi.org/10.1505/ ifor.11.3.299

Hoch, L., B. Pokorny, and W. de Jong. 2012. Financial attractiveness of smallholder tree plantations in the Amazon: bridging external expectations and local realities. Agroforestry Systems 84(3):361-375. http://dx.doi.org/10.1007/s10457-012-9480-1

Homma, A. K. O. 2006. Agricultura familiar na Amazônia: a modernização da agricultura itinerante. Pages 37-60 in I. S. F. Sousa, editor. Agricultura familiar na dinâmica da pesquisa agropecuária. Embrapa Informação Tecnológica, Brasília, Brazil. 
Humphreys, D. 2008. The politics of 'avoided deforestation': historical context and contemporary issues. International Forestry Review 10(3):433-442. http://dx.doi.org/10.1505/ ifor.10.3.433

Humphries, S. S., and K. A. Kainer. 2006. Local perceptions of forest certification for community-based enterprises. Forest Ecology and Management 235(1-3):30-43. http://dx.doi. org/10.1016/j.foreco.2006.07.027

Ibarra, E., M. Romero, and S. Gatter. 2008. Análisis del marco legal para el manejo forestal por pequeños productores rurales en la Amazonia ecuatoriana. SFA, Macas, Ecuador.

Intergovernmental Panel on Climate Change (IPCC). 2007. Climate change 2007. The physical science basis. Working group I contribution to the fourth assessment report. Cambridge University Press, Cambridge, New York.

Jackson, T. 2009. Prosperity without Growth. Economics for a Finite Planet. Earthscan, London, UK.

Kanowski, P., C. McDermott, and B. W. Cashore. 2011. Implementing REDD+: lessons from analysis of forest governance. Environmental Science and Policy 14:111-117. http://dx.doi.org/10.1016/j.envsci.2010.11.007

Karsenty, A., A. Vogel, and F. Castell. In press. Carbon rights, REDD+ and payments for environmental services. Environmental Science and Policy. doi. http://dx.doi. org/10.1016/j. envsci.2012.08 013.

Keen, B., and K. Haynes. 2009. A History of Latin America. $8^{\text {th }}$ edition. Houghton Mifflin Company, Boston, MA, USA. http://dx.doi.org/10.2307/980700

Kissinger, G. 2011. Linking Forests and Food Production in the REDD+ Context. CCAFS Policy Brief 3. [online] URL: http://ccafs. cgiar. org/sites/default/files/assets/docs/

CCAFS_Brief03_web.pdf

Kissinger, G., M. Herold, and V. Sy. 2012. Drivers of Deforestation: a Synthesis Report for REDD+ Policymakers. Lexeme Consulting, Vancouver, Canada.

Larson, A., P. Pacheco, F. Toni, and M. Vallejo. 2006. Exclusión e inclusión en la forestería Latinoamérica: Hacia dónde va la descentralización? IDRC, La Paz, Bolivia.

Larson, A., D. Barry, R. G. Dahal, and C. Colfer. editors. 2010. Forests for People: Community Rights and Forest Tenure Reform. Earthscan, London, UK.

Larson, A., and F. Soto. 2008. Decentralization of natural resource governance regimes. Annual Review of Environment and Resources 33:213-239. http://dx.doi.org/10.1146/ annurev.environ.33.020607.095522

Le Quéré, C., M. R. Raupach, J. G. Canadell, G. Marland et al. 2009. Trends in the sources and sinks of carbon dioxide.
Nature Geoscience 2:831-836. http://dx.doi.org/10.1038/ ngeo689

Lima, E., A. Leite, D. Nepstad, K. Kalif, A. Ramos, and S. Pereira. 2003. Florestas familiares: um pacto sócio-ambiental entre a indústria madeireira e agricultura familiar na Amazônia. IPAM, Belém, Brazil.

Mahar, D. 1988. Government Policies and Deforestation in Brazil's Amazon region, World Bank, Washington D. C., USA.

Margulis, S. 2004. Causes of Deforestation of the Brazilian Amazon, World Bank Working Paper No. 22. World Bank, Washington D. C., US.

Martínez Montaño, J. A. 2008. Marco legal para el manejo forestal por pequeños productores y comunidades en las tierras bajas de Bolivia. CIFOR, Santa Cruz, Bolivia.

Masias, K. 2011. Challenges of Company-community Partnerships within REDD+: a Case Study of Brazil Nut Concessions in Madre de Dios, Peru. MSc thesis. University of Freiburg, Freiburg, Germany.

McDermott, C., A. Helfgott, H. Schroeder, and L. Coad. 2012. Operationalizing social safeguards in REDD+: Actors, interests and ideas. Environmental Science and Policy 21: 63-72. http://dx.doi.org/10.1016/j.envsci.2012.02.007

Medina, G. and B. Pokorny. 2008. Avaliação financeira do manejo florestal comunitário. IBAMA. Brasilia, Brazil.

Medina, G., B. Pokorny, and J. Weigelt. 2009a. The power of discourse: hard lessons for traditional forest communities in the Amazon. Forest Policy and Economics 11:392-397. http:// dx.doi.org/10.1016/j.forpol.2008.11.004

Medina, G., B. Pokorny, and B. Campbell. 2009b. Loggers and development agents exercising power over Amazonian villagers. Development and Change 40(4):745-767. http://dx. doi.org/10.1111/j.1467-7660.2009.01570.x

Medina G., and B. Pokorny B. 2011. Avaliação financeira do manejo florestal comunitário. Novos Cadernos NAEA 14(2): 25-36.

Milz, J. 1997. Guía para el establecimiento de sistemas agroforestales. $2^{\text {nd }}$ edition. DED, La Paz, Bolivia.

Nelson, A. and K. M. Chomitz. 2011. Effectiveness of strict vs. multiple use protected areas in reducing tropical forest fires: a global analysis using matching methods. PLOIS ONE 6(8):e22722. http://dx.doi.org/10.1371/journal.pone.0022722

Pacheco, P., E. Ibarra, P. Cronkleton, and P. Amaral. 2008. Politicas públicas que afectan el manejo forestal comunitario. Pages 201-228 in C. Sabogal, W. de Jong, B. Pokorny and B. Louman, editors. Manejo forestal comunitario en América 
tropical: experiencias, lecciones aprendidas y retos para el future. CIFOR, Bogor, Indonesia.

Pacheco, P. 2009. Agrarian change, cattle ranching and deforestation: Assessing their linkages in Southern Pará. Environment and History 15:493-520. http://dx.doi. org/10.3197/096734009X12532652872072

Pacheco, P., W. de Jong, and J. Johnson. 2010. The evolution of the timber sector in lowland Bolivia: examining the influence of three disparate policy approaches. Forest Policy and Economics 12(4):271-276. http://dx.doi.org/10.1016/j. forpol.2009.12.002

Pacheco, P., D. Barry, A. Larson, and P. Cronkleton. 2012. The recognition of forest rights in Latin America: progress and shortcomings of forest tenure reforms. Society and Natural Resources 26(6):556-571. http://dx.doi. org/10.1080/08941920.2011.574314

Padoch, C. and W. de Jong. 1987. Traditional agroforestry practices of native and peasant farmers of the lowland Peruvian Amazon. Pages 179-194, in H. L. Gholz, editor. Agroforestry: realities, possibilities and potentials. Martinus Nijhof Publishers, Dordrecht, The Netherlands.

Padoch, C., E. Brondizio, S. Costa, M. Pinedo-Vasquez, R. R. Sears, and A. Siqueira. 2008. Urban forest and rural cities: multi-sited households, consumption patterns, and forest resources in Amazonia. Ecology and Society 13(2):2. [online] URL: http://www.ecologyandsociety.org/vol13/iss2/art2/.

Padoch, C., J. Chota, W. de Jong, and J. Unruh. 1985. Amazonian agroforestry: a market-oriented system in Peru. Agroforestry Systems 3:47-58. http://dx.doi.org/10.1007/ $\underline{\mathrm{BF} 00045738}$

Pantoja, M. D. 2008. Acordos entre empresas e comunidades para o manejo florestal: uma análise crítica do caso das comunidades da Reserva Extrativista Rio Preto-Jacundá em Machadinho da Oeste, Rondônia, Brasil. MSc thesis. UFPA, Belém, Brazil.

Parker, E. P. 1985. The Amazon caboclo: historical and contemporary perspectives. College of William and Mary, Williamsburg, VI, USA.

Phillip, M., and B. Pokorny. 2008. Certification of NTFP. Concluding comments. Forest, Trees and Livelihoods 18 (1):91-95. http://dx.doi.org/10.1080/14728028.2008.9752620

Pitman, C. A. N., C. L. M. del Azaldegui, K. Salas, G. Vigo, and A. D. Lutz. 2007. Written accounts of an Amazonian landscape over the last 450 years. Conservation Biology 21 (1):253-262. http://dx.doi.org/10.1111/j.1523-1739.2006.00576. $\underline{\mathrm{X}}$

Pokorny, B. In press. Smallholders, forest management and rural development in the Amazon. Lessons learned from forestry initiatives with smallholders in the Bolivian, Brazilian, Ecuadorian, and Peruvian Amazon. Routlege, The Earthscan Forest Library, London, UK.

Pokorny, B., and J. Johnson. 2008a. Community forestry in the Amazon: The unsolved challenge of forests and the poor. ODI Natural Resource Perspectives 112. ODI, London, UK.

Pokorny, B. and J. Johnson. 2008b. Estrategias de acompañamiento al manejo forestal comunitario. Pages 231278 in C. Sabogal, W. de Jong, B. Pokorny, B. Louman, editors. Manejo forestal comunitario en América Latina: experiencias, lecciones aprendidas y retos para el future. CIFOR, Bogor, Indonesia.

Pokorny, B., and M. Steinbrenner. 2005. Collaborative monitoring of production and costs of timber harvest operations in the Brazilian Amazon. Ecology and Society 10 (1):3. [online] URL: http://www.ecologyandsociety.org/ vol10/iss $1 /$ art3/.

Pokorny, B., W. de Jong, J. Godar, P. Pacheco, and J. Johnson. In press. From large to small: reorienting development policies in response to climate change, food security and poverty. Forest Policy and Economics.

Pokorny, B., J. Johnson, G. Medina, and L. Hoch. 2012. Market-based conservation of the Amazonian forests: revisiting win-win expectations. Geoforum 43(3):387-401. http://dx.doi.org/10.1016/j.geoforum.2010.08.002

Porro, N., C. Germana, C. López, G. Medina, Y. Ramírez, M. Amaral, and P. Amaral. 2008. Capacidades organizativas para el manejo forestal comunitario frente a las demandas y expectativas oficiales. Pages 163-194 in C. Sabogal, W. de Jong, B. Pokorny, and B. Louman, editors. Manejo forestal comunitario en América Latina: experiencias, lecciones aprendidas y retos para el future. CIFOR, Bogor, Indonesia.

Porter-Bolland, L., A. E. Ellis, R. M. Guariguata, I. RuizMallén, S. Negrete-Yankelevich and V. Reyes-García. 2012. Community managed forests and forest protected areas: an assessment of their conservation effectiveness across the tropics. Forest Ecology and Management 268(1):6-17. http:// dx.doi.org/10.1016/j.foreco.2011.05.034

Posey, D. A., E. Parker, L. F. da Silva, and J. Frechione. 1983. Resource exploitation in Amazônia: ethnoecological examples from four populations. Annals of the Carnegie Museum 52(8):163-203.

Posey, D. A., and W. L. Balée. 1987. Resource management in Amazonia: indigenous and folk strategies. New York Botanical Garden, New York, NY, USA.

Randers, J. 2012. 2052: A Global Forecast for the Next Forty Years. Report for the Club of Rome. Chelsea Green, Burlington, VT, USA. 
Ros-Tonen, M. A. F., T. van Andel, C. Morsello, K. Otsuki, S. Rosendo, and I. Scholz. 2008. Forest-related partnerships in Brazilian Amazonia: there is more to sustainable forest management than reduced impact logging. Forest Ecology and Management 256(7):1482-1497. http://dx.doi.org/10.1016/j. foreco.2008.02.044

Rudel, T. K., O. T. Coomes, E. Moran, F. Achard, A. Angelsen, J. Xu, and E. Lambin. 2005. Forest transitions: towards a global understanding of land use change. Global Environmental Change 15:23-31. http://dx.doi.org/10.1016/ j.gloenvcha.2004.11.001

Ruiz, S. A. 2005. Institutional change and social conflicts over forest use in the northern Bolivian Amazon. Freiburger Schriften zur Forst-und Umweltpolitik Band 10. Dr. Kessel, Remagen-Oberwinter, Germany.

Sabogal, C., L. Snook, M. Boscolo, B. Pokorny, L. Quevedo, M. Lentini, and V. Colán. 2007. Adopción de prácticas de manejo forestal sostenible por empresas madereras. Recursos Naturales y Ambientales 49:100-111.

Sabogal, C., J. Nalvarte, and V. Colán. 2008a. Análisis del marco legal para el manejo forestal por pequeños productores y comunidades en la Amazonia Peruana. AIDER, Lima, Peru.

Sabogal, C., W. de Jong, B. Pokorny, and B. Louman, editors. 2008b. Manejo forestal comunitario en América Tropical: experiencias, lecciones aprendidas y retos para el futuro. CIFOR, Bogor, Indonesia.

Sato, R. 2010. Local benefits from payments for environmental services: Exploring the case of bolsa floresta in the Brazilian Amazon. MSc thesis. University of Freiburg, Freiburg, Germany.

Scherr, S., A. White, and D. Kaimowitz. 2001. Making Markets Work for Forest Communities. Forest Trends, Washington D. C., USA. http://dx.doi.org/10.1505/ IFOR.5.1.67.17423

Schmink, M., and C. Wood. 1992. Contested Frontiers in Amazonia. Columbia University Press, New York, NY, USA.

Scholz, I. 2005. Environmental policy cooperation among organised civil society, national public actors and international actors in the Brazilian Amazon. European Journal of Development Research 17(4):681-705. http://dx.doi. org/10.1080/09578810500367466

Schwarzer, H., and A. C. Querino. 2002. Non-contributory pensions in Brazil: The impact on poverty reduction. ESS Paper 11. ILO, Geneva, Switzerland.

Sikor, T., and J. Stahl, editors. 2011. Forests and People: Property, Governance, and Human Rights. Earthscan, New York, NY, USA.
Silva, E., D. Kaimowitz, A. Bojanic, F. Ekoko, T. Manurung, and I. Pavez. 2002. Making the law of the jungle: the reform of forest legislation in Bolivia, Cameroon, Costa Rica, and Indonesia. Global Environmental Politics 2(3):63-97. http:// dx.doi.org/10.1162/152638002320310536

Simmons, S., R. T. Walker, and C. H. Wood. 2002. Tree planting by small producers in the tropics: A comparative study of Brazil and Panama. Agroforestry Systems 56(2):89105 .

Steni, B., and N. Hadad. 2012. REDD+ safeguards in Indonesia, [online] URL: http://www.bicusa.org/en/Document.102891. aspx

Sunderlin, W. D., J. Hatcher, and M. Liddle. 2008. From Exclusion to Ownership? Challenges and Opportunities in Advancing Forest Tenure Reform. RRI, Washington D. C., USA.

Tacconi, L. 2007. Illegal Logging: Law Enforcement, Livelihoods and the Timber Trade. Earthscan, London, UK.

United Nations (UN). 1987. Our Common Future (Brundtland Report). United Nations World Commission on Environment and Development. Oxford University Press, Oxford, UK.

United Nations Development Programme (UNDP). 1997. Manejo, conservación y utilización de los recursos forestales en el trópico de Cochabamba y en las zonas de transición de los Yungas de La Paz. Fase II. AD/BOL/97/C23. La Paz, Bolivia.

United Nations Development Programme (UNDP). 2010. Regional Human Development Report for Latin America and Caribbean 2010: acting on the future breaking the intergeneracional transmission of inequality. UNDP, San José, Costa Rica.

United Nations Framework Convention on Climate Change (UNFCCC). 2011. Report of the conference of the parties on its 16th session, held in Cancun 29 November to 10 December 2010. UN, New York.

United Nations Framework Convention on Climate Change (UNFCCC). 2012. Report of the conference of the parties on its 17th session, held in Durban from 28 November to 11 December 2011. FCCC/CP/2011/9/Add. 1. UN, New York.

van der Werf, G. R., D. C. Morton, R. S. de Fries, J. G. J. Olivier, P. S. Kasibhatla, R. B. Jackson, G. J. Collatz, and J. T. Randerson. 2009. CO2 emissions from forest loss. Nature Geoscience 2:737-738. http://dx.doi.org/10.1038/ngeo671

Viana, V. 2010. Sustainable Development in Practice: Lessons Learned from Amazonas. Environmental Governance 3. IIED, London, UK. 
Wagner, B. A. A. 2008. Terra de quilombo, terras indígenas, "babaçuais livre”, “castanhais do povo”, faixinais e fundos de pasto: terras tradicionalmente ocupadas. $2^{\text {nd }}$ edition. PGSCA/UFAM, Manaus, Brazil.

Wienold, H. 2006. Brasiliens Agrarfront: Landnahme, Inwertsetzung und Gewalt. Peripherie 101/102:43-68.

Wiesse, P. 2012. Piratas del carbón. Revista Ideele. [online] URL: http://www. revistaideele. com/ideele/content/piratasdel-carbono (accessed 9 May 2012).

Wunder, S. 2001. Poverty alleviation and tropical forests what scope for synergies. World Development 19(11):18171833. http://dx.doi.org/10.1016/S0305-750X(01)00070-5

Zeller, M., and R. L. Meyer, editors. 2002. The triangle of microfiance: financial sustainability, outreach, and impact. The John Hopkins University Press, London, GB.

Zenteno, M. 2012. Community Forest Management Success and Forest Management Plans: a Multidimensional Analysis for an on-going Process. $\mathrm{PhD}$ thesis. University of Wageningen, Wageningen, The Netherlands. 